УДК 323.3:316.7

DOI https://doi.org/10.32837/apfs.v0i32.1038

Я. А. Сичова

ORCID ID: https://orcid.org/0000-0003-3820-3033

аспірант кафедри теорї̈ та історії політичної науки

Львівського національного університету імені Івана Франка

\title{
«МІСЦЯ ПАМ'ЯТІ» ЯК ЗАСІБ КОНСТРУЮВАННЯ КОЛЕКТИВНОЇ ІДЕНТИЧНОСТІ
}

Постановка проблеми. В умовах глобалізації спостерігається сплеск інтересу до питання ідентичності національних спільнот. Виклики, які постають перед національними державами й ставлять питання щодо їхньої подальшої долі в мінливому світі глобальних трансформацій, актуалізують процес створення й практичного використання засобів, спрямованих на захист і підтримку ідентичності груп (націй). Позаяк важливою складовою частиною ідентичності будь-якої національної спільноти є колективна пам'ять, що часто стає предметом спотворень, маніпуляцій i, як наслідок, конфліктів, важливого значення набувають дослідження механізмів та інструментів їі конструювання, зокрема «місць пам'яті». Метою останніх є формування колективних уявлень про спільне минуле, а отже, єдиної для спільноти моделі колективної пам'яті, закріплення якої тісно пов’язане з процесами комеморації. У цьому сенсі політичне, що, згідно з М. Фуко, характеризується всепроникністю, переплітається з культурним, і ця взаємодія здатна призвести до інструменталізації історії та пам'яті, а також так званих мнемотичних битв, тобто суперечностей навколо чутливих питань минулого. Владний потенціал «місць пам'яті», а також пов'язані з ними загрози свідчать про необхідність розуміння сутності окресленого феномена та його впливу на конструювання пам' яті національних спільнот.

Аналіз останніх досліджень і публікацій. Варто зауважити, що інтерпретація пам'яті як передумови ідентичності, передусім індивідуальної, має давню традицію в західній філософії (Д. Г'юм, Дж. Локк) [1]. Поняття колективної пам'яті було введене в науковий обіг французьким соціологом М. Хальбваксом, роботи якого започаткували дослідження в межах цієї проблематики. Подальші дослідження зв'язків колективної ідентичності та пам'яті значною мірою спираються на роботи М. Хальбвакса (зокрема їх критику). Серед них слід згадати міждисциплінарні праці А. Ассман, Я. Ассмана, Е. Гобсбаума, Е. Сміта, П. Нора, О. Джеффрі, Н. Геді, Ї. Елам, Дж. Ехтерхофф, М. Саар, Ю. Зарецького, О. Малинової та ін. Концепцію «місць пам'яті», що стала одним із найпотужніших засобів конструювання колективної ідентичності, запропонував французький історик П. Нора в 1980-х роках. Услід за П. Нора, «міс- ця пам'яті» стали предметом дослідницького інтересу M. Хатлі, Г. Байнера, С. Легга, Е. Алькараса, Ж⿱ М. Матьє та ін.

Метою статті є з'ясування особливостей феномена «місць пам'яті» (П. Нора) як засобу конструювання колективної, зокрема національної, ідентичності.

Виклад основного матеріалу. Під «місцями пам'яті» П. Нора має на увазі речові та нематеріальні символи меморіальної спадщини будь-якої національної спільноти [5, с. 54]. Уже на початку 2000 -х років в одній зі статей П. Нора зауважував, що «світ затопила хвиля спогадів» [6, с. 391]. Цю ситуацію дослідник означив як «всесвітне торжество пам'яті». Такої думки дотримуються й інші автори: так, аналізуючи надлишкове звернення до минулого, американський історик Ч. Майер із-поміж характеристик сучасного світу називає панування «меморіальної індустрії», а німецький культуролог А. Ассман вважає сучасну культуру «меморіальною» [3, с. 193]. У дусі конструктивістської парадигми П. Нора засвідчує «відновлення прив' язаності до спадщини» та минулого, яке може бути як реальним, так і уявним [6, с. 391]. У цьому сенсі важливого значення набуває тлумачення нації як «уявленої політичної спільноти» (Б. Андерсон), а пам'яті - як конструкту, для якого важливе значення має міфологічна оповідь.

Передусім зазначимо, що П. Нора визначає ідентичність як тотожність унікальності. Позаяк без самовизначення спільнота не здатна підтримувати своє існування, ідентичність стає обов'язком. 3 огляду на це колективні ідентичності конструюються. На рівні обов'язків виникає тісний зв'язок ідентичності та пам'яті - у цьому випадку «історична самосвідомість перетворюється на соціальну свідомість» [6, с. 400]. Успіх ідеї ідентичності П. Нора пояснює трансформаціями, які торкнулися пам'яті. Зокрема, якщо раніше пам'ять вважали індивідуальним феноменом, то тепер пам'ять належить групі [4, с. 1172]. Це означає, що пам'ять є плюралістичною, тобто доцільно говорити про пал'яті, оскільки кожна група має власну пам'ять. У цьому сенсі пам'ять протистоїть історії, яка є універсальною для всього людства, а отже, претендує на об’єктивний статус.

Торжество пам'яті в Європі П. Нора пов'язує з падінням Берлінської стіни та розпадом 
СРСР. У цей момент пам'ять «здобули» країни Центрально-Східної Європи, які відчули на собі вплив комунізму. «Торжество пам'яті», згідно з П. Нора, полягає в інтересі до минулого - «критиці основних версій історіі», "культі коренів», «бурхливому розвитку різноманітних меморіальних заходів», «зростанні кількості музеїв» та ін. [6, с. 391]. Оскільки минуле, як вважають конструктивісти, зокрема П. Нора, окрім реальних фактів, може містити також вигадки, міфи, з одного боку, постає небезпека свідомої маніпуляції історичними фактами, 3 іншого боку, політика пам'яті може формуватися несвідомо, базуючись на вірі в певні символи.

Феномен пам'яті П. Нора аналізує на прикладі Франції. У 80-90-х роках XX століття завдяки зусиллям П. Нора та низки інших дослідників побачила світ семитомна праця «Місця пам'яті», що стала класикою в контексті досліджень колективної пам'яті. У ній предметом дослідження стали місця (речові й нематеріальні), які є символами для французької нації. Оскільки пам'ять груп із часом зникає, виникає потреба у фіксації пам'яті - створенні місць, які допомагають зберегти зв'язок між минулим, теперішнім і майбутнім. Автор стверджує, що «про пам'ять так багато говорять тільки тому, що її більше немає» [7, с. 17]. Розвиваючи дослідницьку традицію М. Хальбвакса, П. Нора стверджує такий зв'язок: чим менше пам'ять переживається внутрішньо, тим більше зовнішньої підтримки вона потребує [4, с. 1174]. Причому, чим менше залишається пам'яті, тим сильнішою $€$ потреба з «релігійною ревністю» зберігати ії останки - матеріальні та нематеріальні сліди минулого $[7$, с. 30]. Так, коли жива пам'ять (пам'ять очевидців) зникає, постає обов'язок пам'ятати.

3 одного боку, цей обов'язок зумовлений прискоренням історії, тобто постійними трансформаціями та мінливістю світу, у стрімкому потоці якого індивіди та спільноти ризикують втратити самобутність. Через тотальну непередбачуваність майбутнього, а також крах концепції «кінця історії національні спільноти прагнуть зберегти якомога більше свідчень власного минулого - значною мірою для майбутніх поколінь. Оскільки ми не маємо змоги жити в минулому, єдине, що нам доступно, - «говорити» 3 минулим за допомогою слідів, яке воно нам залишає. Ці сліди, на переконання П. Нора, і $є$ ідентичністю [6, с. 396], тоді як звернення до минулого стає можливим лише шляхом його реконструкції у вигляді «місць пам'яті» - меморіалів, архівів, музеїв, історичних документів тощо. Таким чином, щоби остаточно не втратити зв'язок із власним минулим, зберегти спадкоємність, а отже, й ідентичність, національні спільноти мають підтримувати функціонування «місць пам'яті». У цьому сенсі А. Ассман доречно пише про «музеалізацію» «місць пам'яті», пере- дусім травматичних [3, с. 241]. Це своєю чергою $€$ одним із ключових завдань політики національної пам'яті як складника політики ідентичності.

3 іншого боку, обов'язок пам'ятати спричинений потужним рухом різних спільнот, передусім меншин, які мають на меті «відвоювати» власне минуле для утвердження та захисту своєї ідентичності. У цьому сенсі цікавим є кейс країн, які мали досвід гніту тоталітарних режимів. Так, країни Центрально-Східної Європи звертаються до власної пам'яті, зазвичай зруйнованої чи спотвореної цими режимами (комуністичним і націонал-соціалістичним), використовуючи «місця пам'яті» для конструювання сучасних національних наративів. Це своєю чергою є свідченням того, що пам'ять, на відміну від історії, яка перебуває в руках влади, часто $є$ інструментом пригноблених, емансипованих груп. 3 огляду на це, колективна пам'ять позиціонується як інструмент правосуддя - відновлення втраченої справедливості, тому пам'ять «підвладна всім використанням і маніпуляціям, здатна на тривалі приховані періоди та раптові оживлення» $[7$, с. 20]. Оскільки «місця пам'яті» мають на меті продемонструвати й утвердити переконаність у «славному минулому», вони звеличують націю в іï теперішньому та прокладають вектор у «світле майбутнє». Утім, у випадку з тлумаченням пам'яті як відновленням правосуддя на користь пригноблених груп є ризик перетворення пам'яті на знаряддя конфлікту з мотивами виключення Іншого, якого інколи вважають не просто «чужим», а «ворогом» (К. Шмітт).

3 огляду на перераховані вище причини відновлення інтересу до пам'яті важливого значення набуває реконструкція минулого - конструювання колективної пам'яті, засобом якого стають «місця пам'яті» (lieux de mémoire). Власне «місця пам'яті» П. Нора визначає як "останки, крайню форму, в якій існує комеморативна свідомість в історії, що ігнорує іï, але водночас іï потребує» [7, с. 26]. «Місця пам'яті» є продуктом «меморіальної епохи", яка характеризується сплеском інтересу до групової пам'яті. Роль «місць пам'яті» полягає у «відчутті неперервності», з огляду на що передумовою їхнього конструювання є бажання пам'ятати. Оскільки будь-яка пам'ять рано чи пізно перетворюється на історію, національні спільноти потребують створення «місць пам'яті» . 3 цього приводу П. Нора робить логічний висновок: «Якби ми самі продовжували населяти нашу пам'ять, не було би сенсу присвячувати їй особливi місця» [7, с. 19]. Значною мірою це зауваження стосується сучасної доби, коли «весь світ закружляв у цьому танці... глобалізації, демократизації, соціального нівелювання, медіатизації [7, с. 18]. Зважаючи на це, «місця пам'яті» постають як нагадування про минуле, як засіб забезпечення спадкоємності, а отже, підтримання ідентичності. 
Очевидно, що «місця пам'яті» як символи нації та її минулого мають критично важливе значення для національної держави, з одного боку, в еру глобалізації, з іншого - в умовах посилення націоналістичних настроїв (що своєю чергою $€$ реакцією на загрози та виклики глобалізаційних процесів). У час, коли національні спільноти намагаються зберегти якомога більше свідчень власного минулого, роль і значення «місць пам'яті» складно переоцінити. Насамперед це стосується ідентичності. Так, споглядаючи «місце пам'яті», індивід відчуває себе частиною групи, позаяк такі місця-символи мають передусім емоційний вплив. Зазвичай це почуття гордості, патріотизму, шаноби, інколи - смутку, відчаю, а в крайніх випадках - прагнення до реваншу (пам'ять пригноблених груп). Очевидно, що «місця пам' яті» $€$ сакральними для нації, тому виступають засобом інтеграції групи.

До переліку «місць пам'яті» П. Нора зараховує «музеї, архіви, кладовища, колекції, свята, річниці, трактати, протоколи, монументи, храми, асоціації...» [7, с. 26], тобто все те, що, по-перше, репрезентує попередні епохи, по-друге, має важливе силволічне значення, унаслідок чого місця пам'яті здатні хвилювати серця й уми індивідів і груп. Окрім символічного аспекту, необхідними атрибутами «місць пам'яті» $є$ також матеріальна та функціональна складові частини [7, с. 40]. Наприклад, у випадку Франції до «місць пам'яті» П. Нора зараховує Марсельєзу, Пантеон, Тріумфальну арку, словник Ларусса та ін. Усім цим місцям притаманний символізм, або «символічна аура», яка перетворює конкретне місце на об’єкт ритуалу [7, с. 40]. Так, хвилина мовчання не стала би «місцем пам'яті», якби члени групи не поділяли думку про її символічне значення. «Місця пам' яті» вкорінюють вічність у «тут-і-тепер»; зрозуміло, що вони спричиняють ностальгію та глибоку пошану. Вважаємо, саме ностальгія посідає ключове місце серед почуттів, які викликають в індивідів і спільнот «місця пам'яті». Так, наприклад, сучасний польський національний наратив значною мірою спирається на ідею «золотої доби» Польщі до трьох поділів Речі Посполитої наприкінці XVIII століття.

П. Нора виокремлює два види місць пам'яті: панівні, а також ті, над якими панують [7, с. 47]. Панівні «місця пам'яті» $є$ тріумфальними, урочистими та авторитетними - їм завжди присвячують офіційні церемонії, які індивіди зобов'язані відвідувати, навіть усупереч своїй волі. Натомість «місця пам'яті», над якими панують, - це «святилища спонтанної відданості й безмовних паломництв». Вони являють собою «місця-прихисток», «живе серце пам'яті». Як приклад панівних «місць пам'яті» П. Нора наводить похорон Ш. де Голля, який набув національного масштабу через офіційність, тоді як другий різновид «місць пам'яті» ілюструє поховання Ж⿱ Таким чином, панівні «місця пам'яті» конструюються «зверху», позаяк вони базуються на авторитеті та пов'язані з примусом. Своєю чергою другий різновид "місць пам'яті» формується «знизу» - 3 щирого бажання індивідів і спільнот зберегти та увічнити ту пам'ять, яка є для них важливою. Посилаючись на Н. Нора, можна стверджувати, що перші місця постають з обов'язку пал'ятати, тоді як другі - з бажання пам'ятати.

Оскільки «спонтанної пам'яті не існує» [7, с. 26], є потреба у створенні музеїв та відкритті архівів, проведенні меморіальних заходів і святкуванні річниць, формуванні пантеону видатних особистостей і спорудженні пам'ятників. 3 огляду на це актуалізуються обов' язок збереження та заборона знищення, які регулюються на законодавчому рівні. Заборона знищення значною мірою стосується архівів, позаяк імперативом епохи П. Нора називає культ документів. Дослідник підкреслює, що «продовження кількісної революції через кілька десятиліть призведе до помноження кількості тільки суспільних архівів у тисячу разів» [7, с. 30]. Зважаючи на те, що magnum opus автора побачила світ у 80-х роках XX століття, відтоді кількість архівів значно збільшилася. Жодна доба, згідно 3 П. Нора, не характеризувалася такою забобонною повагою до минулого. Особливістю сучасної епохи є те, що бажання написати мемуари може виникнути в будь-якого індивіда. Так, якщо раніше існувала монополія на поповнення архівів (держава, церква), то тепер «хто тільки не бажає записати свої спогади» [7, с. 30]. Меморіальна епоха, таким чином, призводить до «недиференційного розширення меморіального поля, гіпертрофованого роздування функції пам'яті, пов'язаного з відчуттям ïi втрати та відповідним посиленням всіх інститутів пам'яті» [7, с. 30]. Твердження П. Нора підтверджується практикою: так, наприклад, у Польщі, яка у XX столітті мала досвід двох тоталітарних режимів, функціонують Інститут національної пам'яті - Комісія з розслідувань злочинів проти польського народу, а також численні історичні музеї, зокрема такі, що присвячені колективним травмам (Музей Варшавського повстання, Музей Другої світової війни, Музей поляків, які врятували євреїв, тощо). Інститут національної пам'яті існує також в Україні.

Як «місця пам'яті» П. Нора розглядає підручники з історії, автобіографії, щоденники, мемуари. Умовою їх перетворення на «місце пам'яті» $\mathrm{\epsilon}$ «переробка» історії, тобто інтерпретація подій під певним кутом зору. Очевидно, що така інтерпретація має спиратися на інтереси та потреби групи. 3 огляду на це «місця пам'яті» формуються внаслідок «гри історії та пам'яті» [7, с. 40]. Серед «місць пам'яті» П. Нора також розглядає пейза- 
жі, краєвиди, ландшафти, тобто місця, в яких простір набуває символічного виміру. У цьому випадку постає розуміння простору як «нашої землі» («свій - чужий»).

Висновки. Таким чином, у світі, що стрімко змінюється, неабиякого значення набуває збереження зв'язку з традицією, оскільки, згідно з концепцією П. Нора, чим менше пам'ять переживається колективно, тим більше вона потребує створення спеціальних місць - речових і нематеріальних «місць пам'яті», - які дають змогу відчути зв' язок минулого, теперішнього й майбутнього. Головна функція комеморативних практик, репрезентованих «місцями пам'яті», полягає в підтвердженні колективної ідентичності шляхом «пригадування» минулого. При цьому минуле, репрезентоване «місцями пам'яті», може бути як реальним, так i вигаданим, з огляду на що існує загроза маніпулювання історією та їі інструменталізації. В умовах глобальних викликів «місця пам'яті» дають змогу групі назвати себе і таким чином усвідомити власне місце в історії. У «меморіальну епоху» пам' ять здебільшого є інструментом пригноблених груп (із цієї причини політика пам'яті є пріоритетом для правих політичних партій), метою яких є відновлення втраченої справедливості шляхом апелювання до конкретної інтерпретації минулого та вимоги iï визнання з боку Іншого. 3 огляду на це «місця пам'яті» зазвичай звертаються до подій «славного минулого»: королів, лицарів, переможних битв, територіальних завоювань тощо. У такий спосіб група, інструменталізуючи власне минуле, має на меті продемонструвати свою велич, унікальність у цілях теперішнього.

Зазначимо, що концепція «місць пам'яті» П. Нора значною мірою дає змогу визначити та проаналізувати в подальших дослідженнях конкретні інструменти конструювання національної пам'яті (наприклад, музеї, меморіали, архіви, підручники, кінофільми тощо) на прикладі конкретних держав. Це своєю чергою засвідчує доцільність тлумачення колективної пам'яті як засобу конструювання ідентичності спільноти.

\section{Jimepamypa}

1. Steveker L. Identity and Memory. Identity and Cultural Memory in the Fiction of A. S. Byatt. 2009. URL: https://link.springer.com/chapter/10.1057\% 2F9780230248595_8 (дата звернення: 10.11.2021).

2. Ассман А. Новое недовольство мемориальной культурой / пер. с нем. Б. Хлебникова. Москва : Новое литературное обозрение, 2016. 232 с.

3. Ассман А. Длинная тень прошлого: Мемориальная культура и историческая политика / пер. с нем. Б. Хлебникова. Москва : Новое литературное обозрение, 2014. 328 с.

4. Глущенко Г.Ю. Коммеморация как возможность истории. Анализируя Пьера Нора. Молодой ученый. 2015. № 24 (104). C. 1172-1175.
5. Джадт Т. «Места памяти» Пьера Нора: Чьи места? Чья память? Ab imperio. 2004. № 1. С. 44-71.

6. Габович М. Память о войне 60 лет спустя. Россия, Германия, Европа / под ред. М. Габович. Москва : Новое литературное обозрение, 2005. 784 с.

7. Нора П. Франция-память / под ред. П. Нора. Санкт-Петербург : Издательство Санкт-Петербургского университета, 1999. $328 \mathrm{c.}$

\section{Анотація}

Сичова Я. A. «Місця пам'яті» як засіб конструювання колективної ідентичності. - Стаття.

У статті розглядається концепція «місць пам'яті» французького дослідника П. Нора як засіб конструювання колективної ідентичності, формування та захист якої актуалізуються в умовах глобалізаційних викликів і загроз для національних спільнот (розмивання автономії та суверенітету традиційної держави-нації на користь наднаціональних структур, політика мультикультуралізму тощо). Суперечність між національним та наднаціональним, а також неоднозначність вПливів останнього на ідентичність індивідів і груп спричиняють «всесвітне торжество пам'яті», пов'язане 3 надлишковим зверненням до подій минулого («меморіальна індустрія»). Це своєю чергою несе загрозу політизації та інструменталізації історії і, як наслідок, мнемонічних битв - конфліктів, пов'язаних із пам'яттю та інтерпретацією минулого.

У дусі конструктивістської парадигми наголошується на сконструйованості ідентичності й пам'яті, формування яких може спиратися як на реальні факти, так і на вигадку. Розкривається сутність поняття «місця пам'яті», його зв'язок із речовою та нематеріальною спадщиною національних спільнот. Наголошується на відмінностях між універсальною історією та плюралістичними пам'ятями, позаяк кожна спільнота має власну пам'ять та підтримує і захищає їі (політика ідентичності), що несе в собі загрозу спотворень і маніпуляцій. Обгрунтовуються причини «обов'язку пам'ятати", з-поміж яких - прискорення історії (ризик втрати самобутності в умовах глобальних трансформацій) та загальна демократизація (боротьба меншин за утвердження власного минулого). 3'ясовуються мета та види «місць пам'яті» як засобів реконструкції минулого, зокрема музеї, архіви, меморіали, бібліотеки, щоденники тощо. Висвітлюється значення символізму «місць пам'яті» шляхом «переробки історії» - -ії інтерпретації під певним кутом зору, з огляду на що важливого значення в процесі формування «місць пам'яті» набуває міфологічна оповідь.

Ключові слова: пам'ять, ідентичність, місця пам'яті (lieux de mémoire), історія, політика ідентичності.

\section{Summary}

Sychova Ya. A. 'Places of memory' as a means of constructing a collective identity. - Article.

The article considers the concept of 'places of memory' by French researcher P. Nora as a means of constructing a collective identity, the formation and protection of which are actualized in the context of globalization challenges and threats to national communities (erosion of autonomy 
and sovereignty of the traditional nation-state in favor of supranational structures, multiculturalism, etc.). The contradiction between the national and the supranational, as well as the ambiguity of the influence of the latter on the identity of individuals and groups, lead to a 'global celebration of memory' associated with excessive reference to past events (the 'memorial industry'). This, in turn, threatens to politicize and instrumentalize history and, as a result, mnemonic battles - conflicts over memory and interpretation of the past.

In the tradition of the constructivist paradigm, the article focuses on the constructed nature of identity and memory, the formation of which can be based on both real facts and fiction. The essence of the concept of 'places of memory', its connection with the tangible and intangible heritage of national communities is revealed. The differences between universal history and pluralistic memories are emphasized, as each community has its own memory and supports and protects it (identity politics), which carries the risk of distortion and manipulation. The reasons for the 'obligation to remember' are substantiated, including the acceleration of history (the risk of losing identity in the context of global transformations) and general democratization (the struggle of minorities to assert their own past). The purpose and types of 'places of memory' as a means of reconstruction of the past are clarified, including museums, archives, memorials, libraries, diaries, etc. The significance of the symbolism of 'places of memory' through the 'revision of history', i.e. its interpretation from a certain point of view, is highlighted. Given this, the mythological narrative becomes important in the process of forming 'places of memory'.

Key words: memory, identity, places of memory (lieux de mémoire), history, identity politics. 